\title{
SENSORY CHARACTERISTICS OF 'DOURADÃO' PEACHES SUBMITTED TO MODIFIED ATMOSPHERE PACKAGING ${ }^{1}$
}

\author{
LIGIA REGINA RADOMILLE DE SANTANA², BENEDITO CARLOS BENEDETTI ${ }^{3}$, \\ JOSÉ MARIA MONTEIRO SIGRIST ${ }^{4}$
}

\begin{abstract}
The sensory, physical and chemical characteristics of 'Douradão' peaches cold stored in different modified atmosphere packaging (LDPE bags of 30, 50, 60, 75 $\mu$ m thickness) were studied. After 14, 21 and 28 days of cold storage $\left(1 \pm 1{ }^{\circ} \mathrm{C}\right.$ and $\left.90 \pm 5 \% \mathrm{RH}\right)$, samples were withdrawn from MAP and kept during 4 days in ambient air for ripening. Descriptive terminology and sensory profile of the peaches were developed by methodology based on the Quantitative Descriptive Analysis (QDA). The assessors consensually defined the sensory descriptors, their respective reference materials and the descriptive evaluation ballot. Fourteen individuals were selected as judges based on their discrimination capacity and reproducibility. Seven descriptors were generated showing similarities and differences among the samples. The data were analysed by ANOVA, Tukey test and Principal Component Analysis (PCA). The atmospheres that developed inside the different packaging materials during cold storage differed significantly. The PCA showed that MA50 and MA60 treatments were more characterized by the fresh peach flavour, fresh appearance, juiciness and flesh firmness, and were effective for keeping good quality of 'Douradão' peaches during $28 \mathrm{~d}$ of cold storage. The Control and MA30 treatments were characterized by the mealiness, the MA75 treatment showed lower intensity for all attributes evaluated and they were ineffective to maintain good quality of the fruits during cold storage. Higher correlation coefficients (positive) were found between fresh appearance and flesh firmness (0.95), fresh appearance and juiciness (0.97), ratio and intensity of fresh peach smell $(0.81)$, as well as higher correlation coefficients (negative) between Hue angle and intensity of yellow colour (-0.91), fresh appearance and mealiness (-0.92), juiciness and mealiness (-0.95), firmness and mealiness (-0.94).

Index terms: Prunus persica, chilling injury, woolliness, Quantitative descriptive analysis.
\end{abstract}

\section{CARACTERÍSTICAS SENSORIAIS DE PÊSSEGOS 'DOURADÃO’ ARMAZENADOS SOB ATMOSFERA MODIFICADA}

RESUMO - Foram avaliadas as características sensoriais, físicas e químicas de pêssegos 'Douradão' armazenados sob refrigeração e diferentes condições de atmosfera modificada (sacos de PEBD nas espessuras de 30; 50; 60 e $75 \mu \mathrm{m})$. Após 14; 21 e 28 dias de estocagem refrigerada $\left(1 \pm 1{ }^{\circ} \mathrm{C}\right.$ e $90 \pm 5 \%$ UR), as embalagens plásticas foram retiradas, e as amostras foram mantidas sob ar ambiente durante 4 dias para amadurecimento. A terminologia descritiva e os perfis sensoriais dos pêssegos foram desenvolvidos baseados na Análise Descritiva Quantitativa (ADQ). Os provadores, consensualmente, definiram descritores sensoriais, os respectivos materiais de referência e a ficha de avaliação. Quatorze provadores foram selecionados de acordo com sua capacidade de discriminação e reprodutibilidade. Sete descritores foram gerados, mostrando similaridades e diferenças entre as amostras. Os dados foram analisados por ANOVA, teste de Tukey e Análise de Componentes Principais (ACP). Durante a estocagem refrigerada, as atmosferas desenvolvidas dentro das embalagens diferiram significativamente. AACP mostrou que os tratamentos AM50 e AM60 foram mais caracterizados pelo sabor de pêssego fresco, aparência de pêssego fresco, suculência e firmeza da polpa, e foram efetivos na manutenção da boa qualidade dos pêssegos 'Douradão', durante 28 dias de armazenamento refrigerado. Os tratamentos AM30 e Controle foram caracterizados pela lanosidade; o tratamento AM75 apresentou as menores intensidades para os atributos avaliados, e eles foram ineficientes na manutenção da qualidade dos frutos frigoconservados. Foram encontrados altos coeficientes de correlação (positivo) para aparência fresca e firmeza da polpa $(0,95)$, aparência fresca e suculência $(0,97)$, "ratio" e intensidade de aroma de pêssego fresco $(0,81)$, assim como, altos coeficientes de correlação (negativo) entre ângulo Hue e intensidade de cor amarela da polpa $(-0,91)$, aparência fresca e lanosidade $(-0,92)$, suculência e lanosidade $(-0,95)$, firmeza da polpa e lanosidade $(-0,94)$.

Termos para indexação: Prunus persica, injúria pelo frio, lanosidade, análise descritiva quantitativa.

'(Trabalho 187-09). Recebido em: 12-08-2009. Aceito para publicação em: 10-03-2010. Parte do Projeto de Pesquisa "Conservação de pêssego cv. Dourado-2 sob atmosfera controlada", financiado pela FAPESP (Processo n.2006/03659-0).

${ }^{2}$ Prof $^{4}$. Dra. Departamento Ciências da Vida, UNEB/Faculdade de Nutrição, Av. Silveira Martins, n.2555, 41195-001, Salvador-BA, Brasil, E-mail: ligiarrs@ig.com.br, 1rsantana@uneb.br

${ }^{3}$ Prof. Dr. Faculdade de Engenharia Agrícola-UNICAMP, C.P. 6011, 13083-875, Campinas-SP, Brasil, E-mail: benedeti@agr.unicamp.br ${ }^{4}$ Pesquisador Dr. Grupo de Engenharia e Pós-colheita- ITAL, C.P. 130, 13001-970, Campinas-SP, Brasil, E-mail: jmms@ital.sp.org.br 


\section{INTRODUCTION}

Peaches (Prunus persica L) available in the supermarkets generally lack the quality that consumers expect. One factor that contributes greatly to peach quality loss is chilling injury that limits the storage life of peaches under low temperature. Although the fruits have a good appearance when removed from cold storage, they fail to ripen satisfactorily and evolve excessive flesh softening, dryness and mealy or woolly texture and flesh browning. This disorder is not externally visible fruits are often marketed at this stage, leading to decreased consumer acceptance. The 'Douradão' peach is one of the most important cultivar grown in São Paulo State, Brazil. These fruits have shown preference by consumers whom have mentioned it as having the best qualitative characteristics like sweet taste, intense cover color and big size, and by traders and their clients, mainly due to the higher prices tendency. However, nonripe fruits are susceptible to chilling injury when cold stored temperature lower $5^{\circ} \mathrm{C}$ for period bigger than 14 days.

Modified atmosphere packaging (MAP) is commonly used to maintain the quality and improve the storage life of fruit and vegetables. Atmospheric modification evolves within the package as a result of the respiration rate of the plant tissue and the gas diffusion characteristics of the film. Film selection is important, since a proper matching of the commodity characteristics with the permeability of the film results in the evolution of an appropriate atmosphere within the sealed package (KADER et al., 1989). Peaches can benefit from $12 \% \mathrm{O}_{2}$ and $510 \% \mathrm{CO}_{2}$ atmospheres at low temperatures (KADER, 1997). Studies have showed that MAP slowed down the respiration rate of peach and nectarine and retarded the decrease in titratable acidity values, maintained the fruit sugar and soluble solids content, flesh firmness, vitamin $\mathrm{C}$ and juice content, and slowed deterioration through decreasing fruit injury and browning rates. To characterize how MAP affects fruits quality, changes have traditionally been assessed in terms of single attributes such as colour, texture changes or the development of off-odours (DEILY;RIZVI, 1983; ZOFFOLI et al., 1998).

In order to maintain eating and market quality of fruits it is important to know their sensory characteristics like smell, flavour, texture and appearance, which can be studied by methodology based on the Quantitative Descriptive Analysis (QDA), that provide a complete description of their sensory properties, being one of more complete and reliable method for characterization of food attributes
(STONE;SIDEL, 1985). Thus, the objective of this work was to evaluate the effect of modified atmosphere packaging (MAP) and cold storage on the sensory characteristics of 'Douradão' peaches using QDA.

\section{MATERIALS AND METHODS}

Freshly harvested 'Douradão' peaches were obtained from a commercial orchard in Jarinu, São Paulo. The fruits were selected according to size and skin background color (green-yellow) and immediately pre-cooled to $5^{\circ} \mathrm{C}$. Before pre-cooling, 72 peaches were randomly sampled and placed in 6 nonwrapped polypropylene (PP) trays, containing 12 peaches each, which were held in ambient air during 4 days for ripening. On the same day of harvest (3 trays) and on the $4^{\text {th }}$ day of ripening ( 3 trays, each tray constituted a replicate), the peaches were evaluated for sensory, physical and chemical characteristics of flesh colour (Hue angle, lightness), soluble solids content, titratable acidity, ratio (SSC/TA) and $\mathrm{pH}$.

The fruits were randomly distributed into 5 lots (entirely randomized design), one was held in nonwrapped PP trays (Control) at air and the others were placed in similar PP trays, inserted in bags of low density polyethylene (LDPE) film (Altaplast Ltda), where gas mixture of $10 \mathrm{kPa} \mathrm{CO}_{2}+1.5 \mathrm{kPa}$ $\mathrm{O}_{2}$ (balance $\mathrm{N}_{2}$ ) was injected and packages were sealed (Selovac, 200B). The following treatments were tested: $\left(\mathrm{T}_{1}\right)$ Control: nonwrapped PP trays, $\left(\mathrm{T}_{2}\right)$ MA30: LDPE film of $30 \mu \mathrm{m}$ thickness, $\left(\mathrm{T}_{3}\right)$ MA50: LDPE film of $50 \mu \mathrm{m}$ thickness, $\left(\mathrm{T}_{4}\right)$ MA60: LDPE film of $60 \mu \mathrm{m}$ thickness, $\left(\mathrm{T}_{5}\right)$ MA75: LDPE film of $75 \mu \mathrm{m}$ thickness. All treatments were stored during 28 days at $1 \pm 1{ }^{\circ} \mathrm{C}$ and relative humidity (RH) of $90 \pm 5 \%$. After 14, 21 and 28 days, fruits were taken from cold storage, the LDPE films removed and 3 trays per treatment were held in air at $25^{\circ} \mathrm{C} 90 \pm$ $5 \% \mathrm{RH}$ during 4 days for ripening (each replicate containing 12 peaches). Quality parameters were determined on the same day of removal and on the $4^{\text {th }}$ day of ripening, as mentioned to the fruits at harvest.

Ethical clearance approval for this work was granted by the Research Ethics Committee, Faculty of Medical Science (UNICAMP). Sixteen candidates were pre-screened based on availability, general food habits, ability to discriminate differences between products and to describe their perceptions. Six training sessions were carried out during two weeks. Sensory descriptors for odour, texture, flavour and appearance attributes were developed through brainstorming about the similarity and differences 
among the samples of peaches (MOSKOWITZ, 1983). The next step of the training was the definition of each descriptive term under supervision of a leader that aimed to join similar descriptive terms and to produce reference samples using a roundtable consensus (Table 1). The training was finished when the individuals had no difficulties to evaluate the samples using the evaluation ballot. In a final session, each sample was evaluated in triplicate by each assessor, using a complete block in the statistical design. Statistical evaluation was performed through analysis of variance (ANOVA), and for each assessor were calculated the significance levels $(\mathrm{p})$ for the $\mathrm{F}$ test (samples and replicates). The individuals were selected as judges using the following criterions: discrimination power $\left(\mathrm{pF}_{\text {samples }}<0.50\right)$, reproducibility ( $\mathrm{F} \mathrm{F}_{\text {replicates }} \geq 0.05$ ), according to Damasio \& Costell (1991) methodology.

The Quantitative Descriptive Analysis method (STONE;SIDEL, 1985) was used to describe the differences among 'Douradão' peach samples depending on packaging material and cold storage period. For the sensory evaluation was used statistical design of complete block, with 3 replicates. The tests were conducted on individual sensory booths under daylight, the slices of peeled peach $(30 \mathrm{~g})$ at room temperature $\left(25^{\circ} \mathrm{C}\right)$ were placed in individual three-digit-coded plastic plates and were presented to assessors one at a time in a randomized design, for cleansing the palate between the samples was used filtered water. On unstructured scales of $9 \mathrm{~cm}$ labeled on both ends, with descriptive terms in the left (lower anchor) and in the right (upper anchor), the assessors rated the intensity of each descriptor for each sample, using the following order: fresh peach smell (scales labeled low to high presence), yellow colour (light to dark), fresh appearance (unacceptable to excellent), fresh peach flavour (low to high presence), flesh firmness (soft to firm), juiciness (not juicy to very juicy), mealiness (not mealy to very mealy).

On each day of evaluation, ten fruits were randomly removed from 3 trays to evaluation of physical and chemical characteristics. The fruits were cut into two halves and the colour was measured on two equidistant points of the equatorial zone of peach, in both sides, using a tristimulus colorimeter (Minolta CR-300), to obtain the $a^{*}, b^{*}$ and $L^{*}$ parameters. The equipment was calibrated with a white standard RSEX n.6299 ( $x=77.46 ; y=82.08 ; z=88.38)$. The Hue angle value $\left(\mathrm{H}^{*}=\arctan \left(\mathrm{b}^{*} / \mathrm{a}^{*}\right)\right.$, where $\mathrm{a}^{*}=$ redness value and $b^{*}=$ yellowness value) was calculated according McGuirre (1992). Segments from each fruit were homogenized using a commercial blender (Philips) and SSC ( ${ }^{\circ}$ Brix) was measured with a hand refractometer (Atago). TA was determined by titrating $10 \mathrm{~g}$ of the homogenized pulp with 0.01 $\mathrm{NaOH}$ to an endpoint of $\mathrm{pH} 8.1$ (Micronal Titrator), and results expressed as $\mathrm{g}$ of malic acid in $100 \mathrm{~g}^{-1}$ sample (AOAC, 1995). The $\mathrm{pH}$ was determined through direct read using the same equipment. The ratio SSC/TA was determined.

An ANOVA was performed (F test) and the treatment means were compared by the Tukey multiple range test at $\mathrm{p} \leq 0.05$, using the SAS statistical package (SAS, 2003). The values at harvest and after each storage period were compared to find significant differences among treatments. Principal component analysis (PCA) was performed on the averages of subjects and replicates in order to describe the main variation in the sensory data and the correlation matrix was obtained to attributes. For instrumental-sensory comparisons, raw data was used to calculate Pearson correlation coefficients (0.05 level of significance).

\section{RESULTS AND DISCUSSION}

The quantitative descriptive analysis showed that the sensory properties (appearance, odour, flavour and texture) of the 'Douradão' peaches were affected by the packaging material and cold storage period used in this study (Tables 2 and 3). The PCA (Figure 1) showed that MA50 and MA60 treatments were more characterized by the fresh peach flavour, fresh appearance, juiciness and flesh firmness. The Control and MA30 treatments were characterized by the mealiness. The treatment MA75 showed lower intensity for the attributes evaluated, possibly due to the anoxia in the fruits (fermentation smell and taste). The fruits evaluated after harvest showed higher intensity for yellow colour and fresh peach smell. The two principal components were used together and explained $96.6 \%$ of the total variability observed among the treatments. There was high positive correlation (0.95) between fresh appearance and flesh firmness, as well as fresh appearance and juiciness (0.97), probably the firmer and more juicy fruits presented an overall impression of the freshness. The opposite was found between fresh appearance and mealiness that showed high negative correlation $(-0.92)$. The juiciness and the mealiness presented high negative correlation (-0.95), the same way firmness and mealiness $(-0.94)$, certainly the fruits with more woolly and dry texture released little amount of juice on chewing and required lower force in the bite.

Akbudak and Eris (2004) studied physical, chemical and sensory changes in 'Flavorcrest' and 
'Red Top' peaches and 'Fantasia' and 'Fairlane' nectarines during storage at $0{ }^{\circ} \mathrm{C}$ in modified atmosphere packaging by using $30 \mu \mathrm{m}$ PP (polypropylene) and $45 \mu \mathrm{m}$ PE (polyethylene) plastic bags. In the sensory analysis, the authors evaluated odour, flavour and overall quality of the fruits through the use of a ten-centimeters nonstructure scale with the intensity terms anchored at its ends $(0=$ unacceptable and $10=$ excellent $)$. They reported that control treatment (fruits maintained in air) showed lower scores for all evaluated attributes and the MAP treatments (PP and PE) showed higher scores for the same attributes. Peaches 'Flavorcrest' and nectarine 'Fantasia' could be stored for 30 and 45 days using PP and PE, respectively. Peaches 'Red Top' and nectarine 'Fairlane' stored successfully for up to 45 days using the same cover materials.

MAP had influence on flesh colour after 28 days cold storage. The Hue angle value of Control treatment was lower and differed significantly from MA60 and MA75 treatments. After 4 days ripening, decrease in Hue angle values were detected for all treatments, with higher decrease for the Control and MA30 treatments, that differed significantly from others MAP treatments (Table 4). MAP treatments probably inhibited chlorophyll degradation and carotenoids synthesis; cold temperature and changes in atmosphere during the storage of fruits have been found to affect the physiology and biochemistry of the fruits (CHITARRA;CHITARRA, 2005). After all cold storage periods no significant changes in lightness $\left(\mathrm{L}^{*}\right)$ on Control and MAP treatments were found, and no significant difference with fruit at harvest. However, after the exposure at room temperature, decrease in $\mathrm{L}^{*}$ values were detected for all treatments, with higher decrease for the Control and MA30 treatments, that differed significantly from others MAP treatments and those values at harvest. Hue angle values showed high correlation (negative) with sensory scores for intensity of yellow colour $(r=-0.92)$, significant at 5\% level. However, lightness showed low correlation with sensory scores for fresh appearance $(r=0.51)$.

Similar tendencies were obtained by Santos (2007), with 'Douradão' and Feippe and Villas Boas (2001), with 'Marly' in their studies with peaches cold stored under MAP, the fruits maintained in LDPE bags showed higher L* values than control fruits, confirming the effect of MAP on keeping lightness of fruits, during their shelf life, after transfer to air.

The fruits from MAP showed lower ratio values, due to low increase of SSC (8.60-10.50) and low decrease of TA $(0.30-0.26)$ along the cold storage period. Control treatment reached higher levels, probably MAP delayed fruit ripening. After the exposure at room temperature, a significant increase in SSC/TA was detected under all treatments (Table 4), although MA75 treatment reached lower ratio value, because fermentation and differed significantly from the others treatments and that evaluated immediately after harvest. Ratio values were better correlated with sensory scores for intensity of fresh peach smell $(r=0.81)$ than for intensity of fresh peach flavour $(\mathrm{r}=0.63)$, at $5 \%$ significance level.

Girardi et al. (2002) and Akbudak e Eris (2004) studying cold storage of peach and nectarine under MAP support the results obtained on this study with respect to delay the fruit ripening. The authors mentioned lower SSC to MAP treatments and higher level on control after cold storage and after shelf life. 


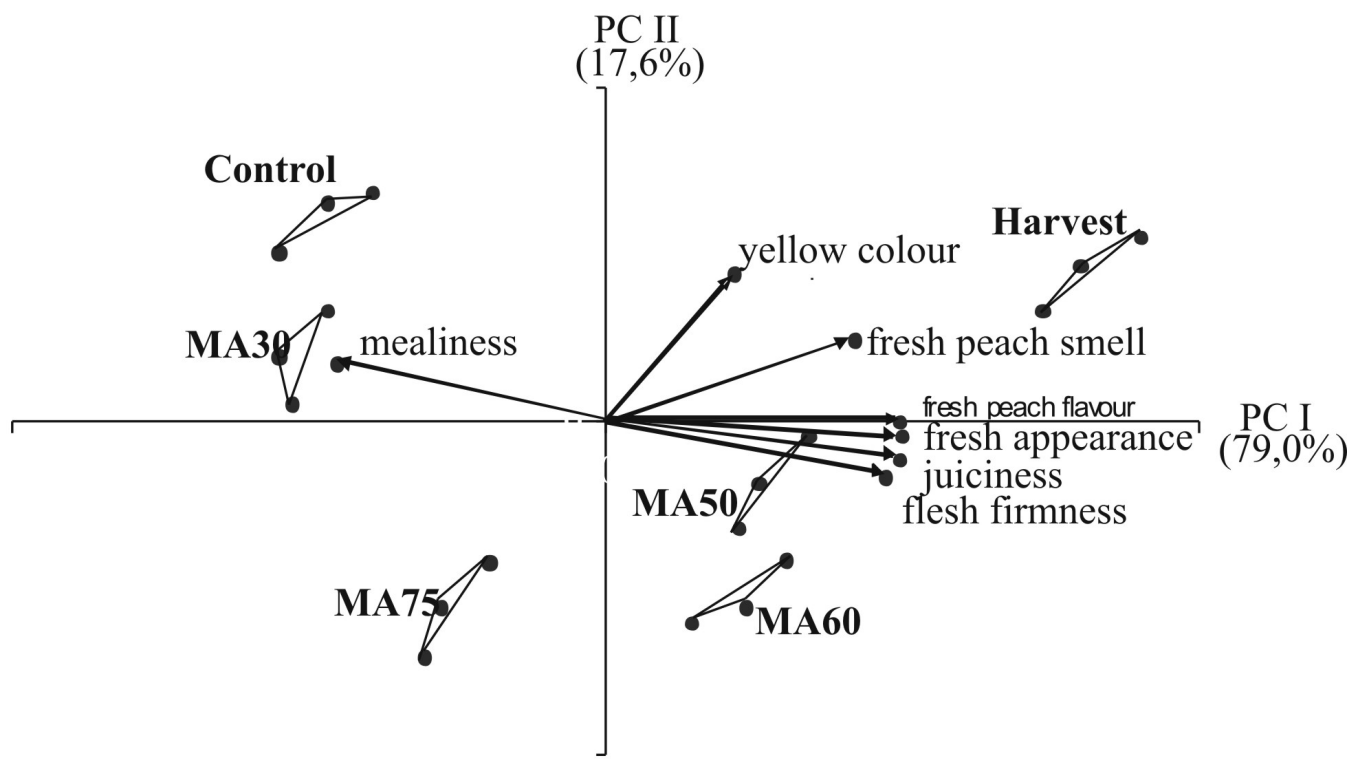

FIGURE 1 - Principal Component Analysis (PCA) of sensory data of 'Douradão' peaches after 28 days cold storage at $1 \pm 1{ }^{\circ} \mathrm{C}$ under MAP plus 4 days ripening in air at $25^{\circ} \mathrm{C}$. PCA loadings and scores for principal component 1 and 2, including all evaluated sensory attributes.

TABLE 1 - Descriptive terms and reference materials used during panel training and quantitative descriptive analysis sessions*.

Attributes

Definitions

$\begin{aligned} & \text { Fresh peach } \\ & \text { Freshness degree of peach. } \\ & \text { smell }\end{aligned}$
Smell of fresh newly cut peach.

Yellow colour Shade of yellow colour variable from light yellow to dark yellow.

Light: $10 \mathrm{~mL}$ of UHT whole milk plus 10 drops of A. Dark: $10 \mathrm{~mL}$ of UHT whole milk plus 20 drops of A. $\mathrm{A}=1$ drop of natural urucum coloring $(\mathrm{A}-260-\mathrm{WS})$ diluted in $5 \mathrm{~mL}$ of water.

Fresh Overall impression of the freshness. appearance

Fresh peach Flavour of fresh newly cut peach. flavour

Firmness Force required biting with the front teeth.

Juiciness

Amount of juice released on first bite.

Woolly and dry texture on chewing.
Low: slices of peach cut $24 \mathrm{~h}$ before.

High: slices of freshly cut peach.
Mealiness
Unacceptable: darkness, dry and soft flesh.

Excellent: yellow shade, juicy and firm flesh.

Low: slices of peach cut $24 \mathrm{~h}$ before.

High: slices of freshly cut peach.

Soft: slices of injury and damaged peach.

Firm: slices of entire and hard peach.

Absent: slices of dry peach, without juiciness.

High: slices of freshly cut peach, vey juicy.

Absent: slices of peach very juicy. High: slices of woolly and dry peach.

*Results expressed on unstructured scales of $9 \mathrm{~cm}$ labeled on both ends, with descriptive terms in the left (lower anchor) and in the right (upper anchor). 
TABLE 2 - Mean values for the appearance, colour, odour and flavour of 'Douradão' peaches after harvest and under MAP after cold storage (CS) at $1 \pm 1{ }^{\circ} \mathrm{C}$ during 14, 21 and 28 days, plus 4 days ripening in air at $25 \pm 1{ }^{\circ} \mathrm{C}$.

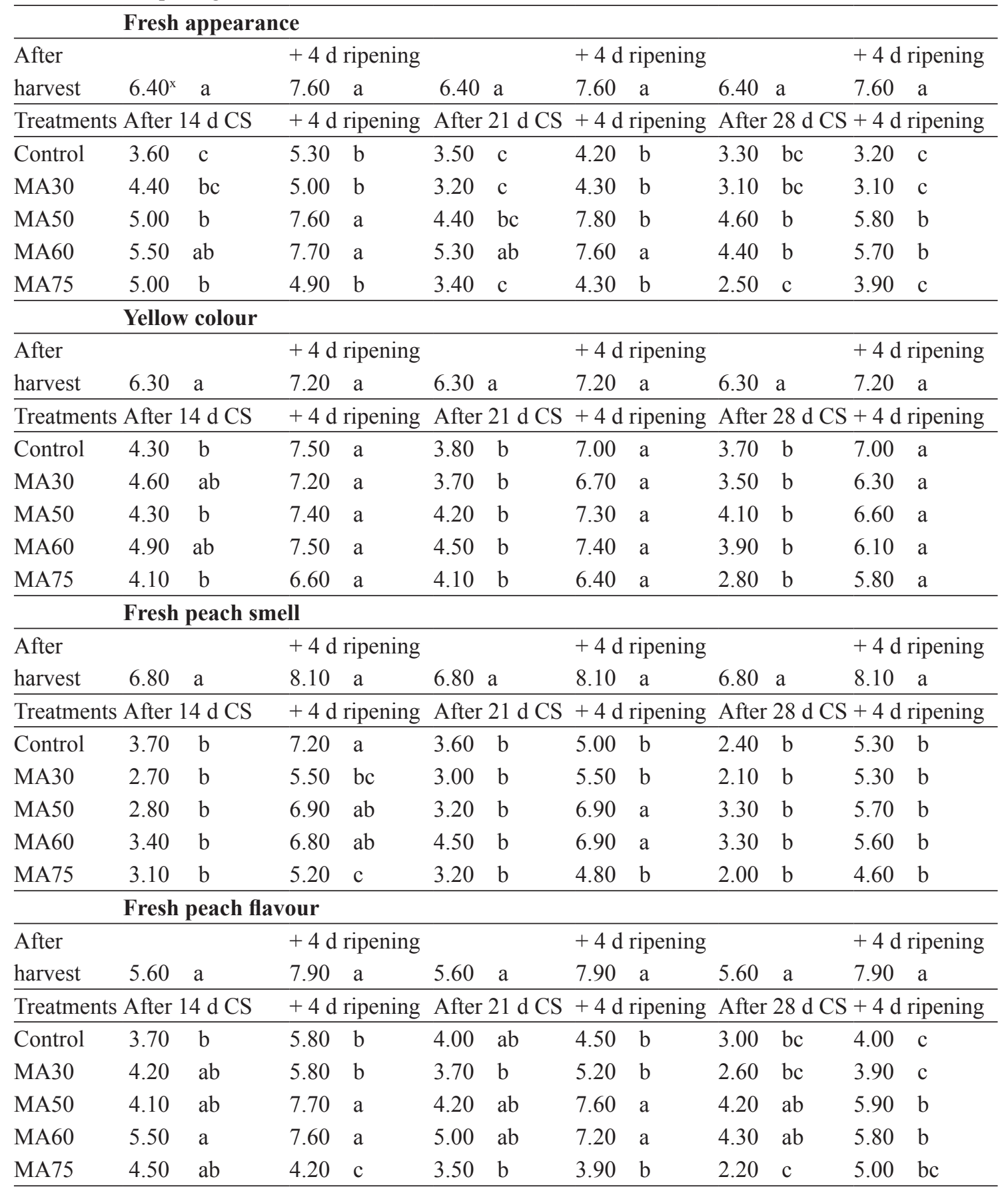

${ }^{\mathrm{x}}$ Average $(\mathrm{n}=14)$.

Control $=$ nonwrapped; MA30 $=$ PEBD30 $\mu \mathrm{m} ;$ MA50 = PEBD50 $\mu \mathrm{m} ;$ MA60 = PEBD60 $\mu \mathrm{m} ;$ MA75 = PEBD75 $\mu \mathrm{m}$.

For each parameter, in the column, same letters no differ significantly between each other, according to Tukey test ( $\mathrm{p} \leq 0.05)$. 
TABLE 3 - Mean values for the texture (flesh firmness, juiciness and mealiness) of 'Douradão' peaches after harvest and under MAP after cold storage (CS) at $1 \pm 1{ }^{\circ} \mathrm{C}$ during 14, 21 and 28 days, plus 4 days ripening in air at $25 \pm 1{ }^{\circ} \mathrm{C}$.

\section{Flesh firmness}

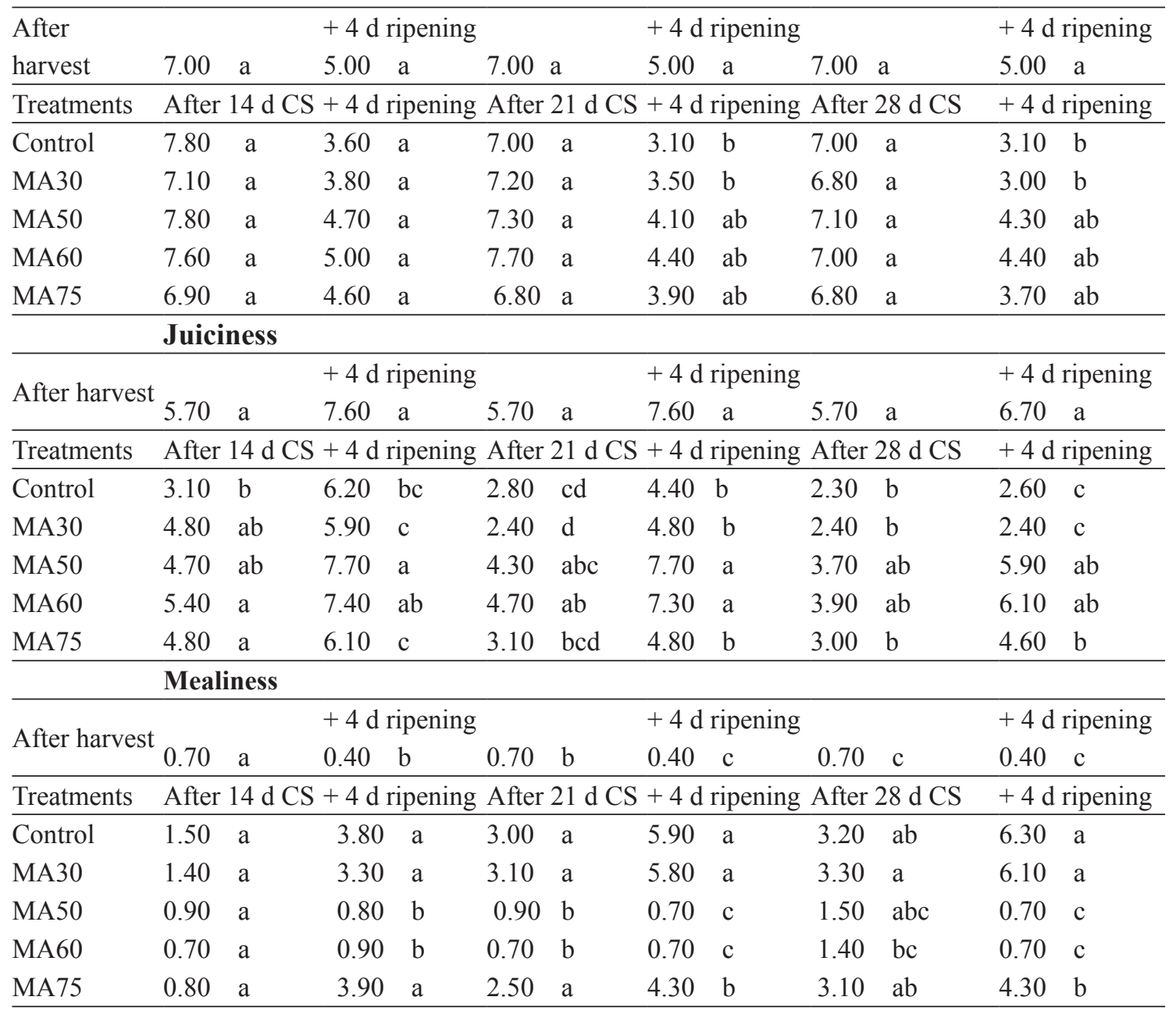

${ }^{\mathrm{x}}$ Average $(\mathrm{n}=14)$.

Control $=$ nonwrapped; MA30 $=$ PEBD30 $\mu \mathrm{m} ; \mathrm{MA50}=\mathrm{PEBD} 50 \mu \mathrm{m} ; \mathrm{MA60}=\mathrm{PEBD} 60 \mu \mathrm{m} ; \mathrm{MA75}=\mathrm{PEBD} 75 \mu \mathrm{m}$.

For each parameter, in the column, same letters no differ significantly between each other, according to Tukey test $(\mathrm{p} \leq 0.05)$. 
TABLE 4 - Mean values for the Hue angle, lightness and ratio (soluble solids content/titratable acidity) of 'Douradão' peaches after harvest and under MAP after cold storage (CS) at $1 \pm 1{ }^{\circ} \mathrm{C}$ during 14,21 and 28 days, plus 4 days ripening in air at $25 \pm 1{ }^{\circ} \mathrm{C}$.

\begin{tabular}{|c|c|c|c|c|c|c|}
\hline \multirow{3}{*}{$\begin{array}{l}\text { After } \\
\text { harvest }\end{array}$} & \multicolumn{6}{|l|}{ Hue angle } \\
\hline & \multicolumn{3}{|c|}{$+4 \mathrm{~d}$ ripening } & \multicolumn{2}{|l|}{$+4 \mathrm{~d}$ ripening } & \multirow{2}{*}{$\begin{array}{l}+4 \mathrm{~d} \text { ripening } \\
85.91 \pm 1.61 \mathrm{a}\end{array}$} \\
\hline & $88.33^{x} \pm 0.87^{y} a$ & $85.91 \pm 1.61 \mathrm{a}$ & $88.33 \pm 0.87 \mathrm{a}$ & $85.91 \pm 1.61 \mathrm{a}$ & $88.33 \pm 0.87 \mathrm{a}$ & \\
\hline Treatments & After $14 \mathrm{~d} \mathrm{CS}$ & $+4 \mathrm{~d}$ ripening & After $21 \mathrm{~d} \mathrm{CS}$ & $+4 \mathrm{~d}$ ripening & After $28 \mathrm{~d} \mathrm{CS}$ & $+4 \mathrm{~d}$ ripening \\
\hline ontrol & $87.74 \pm 1.49 \mathrm{a}$ & $82.28 \pm 1.45 b$ & $86.65 \pm 2.36 \mathrm{a}$ & $82.25 \pm 1.48 \mathrm{c}$ & $86.07 \pm 2.20 \mathrm{~b}$ & $78.90 \pm 1.32 \mathrm{~d}$ \\
\hline 1A30 & $87.35 \pm 1.86 \mathrm{a}$ & $82.11 \pm 1.66 b$ & $87.10 \pm 2.29 \mathrm{a}$ & $82.91 \pm 1.51 \mathrm{bc}$ & $87.36 \pm 1.32 \mathrm{ab}$ & $82.15 \pm 1.50 \mathrm{c}$ \\
\hline MA50 & $88.70 \pm 1.80 \mathrm{a}$ & $84.88 \pm 1.25 \mathrm{a}$ & $88.39 \pm 1.31 \mathrm{a}$ & $84.28 \pm 1.71 \mathrm{ab}$ & $87.39 \pm 1.06 \mathrm{ab}$ & $84.12 \pm 1.75 b$ \\
\hline IA60 & $88.00 \pm 1.66 \mathrm{a}$ & $84.70 \pm 1.49 \mathrm{a}$ & $87.11 \pm 2.34 \mathrm{a}$ & $85.13 \pm 1.95 \mathrm{a}$ & $88.29 \pm 1.27 \mathrm{a}$ & $84.05 \pm 1.42 b$ \\
\hline \multirow[t]{2}{*}{ MA75 } & $88.92 \pm 1.81 \mathrm{a}$ & $84.30 \pm 1.59 \mathrm{a}$ & $87.12 \pm 1.28 \mathrm{a}$ & $85.12 \pm 1.09 \mathrm{a}$ & $88.06 \pm 1.54 \mathrm{a}$ & $84.09 \pm 1.88 \mathrm{~b}$ \\
\hline & \multicolumn{6}{|l|}{ Lightness $\left(\mathrm{L}^{*}\right)$} \\
\hline \multirow{2}{*}{$\begin{array}{l}\text { After } \\
\text { harvest }\end{array}$} & \multicolumn{3}{|c|}{$+4 \mathrm{~d}$ ripening } & \multicolumn{2}{|l|}{$+4 \mathrm{~d}$ ripening } & oening \\
\hline & $72.05 \pm 1.52 \mathrm{a}$ & $69.72 \pm 1.69 \mathrm{ab}$ & $72.05 \pm 1.52 \mathrm{a}$ & $69.72 \pm 1.69 \mathrm{~cd}$ & $72.05 \pm 1.52 \mathrm{a}$ & $69.72 \pm 1.69 \mathrm{bcd}$ \\
\hline Treatments & After 14 d CS & $+4 \mathrm{~d}$ ripening & After $21 \mathrm{~d} \mathrm{CS}$ & $+4 \mathrm{~d}$ ripening & After $28 \mathrm{~d} \mathrm{CS}$ & $+4 \mathrm{~d}$ ripening \\
\hline Control & $71.99 \pm 2.34 \mathrm{a}$ & $69.64 \pm 1.04 \mathrm{~b}$ & $70.28 \pm 2.19 \mathrm{a}$ & $68.59 \pm 1.52 \mathrm{~d}$ & $70.09 \pm 1.54 \mathrm{a}$ & $67.69 \pm 1.25 \mathrm{~d}$ \\
\hline & & $70.29 \pm 1.41 \mathrm{ab}$ & & $71.84 \pm 1.19 \mathrm{ab}$ & $71.67 \pm 1.48 \mathrm{a}$ & $68.95 \pm 2$ \\
\hline IA50 & $71.89 \pm 1.10 \mathrm{a}$ & $71.76 \pm 1.97 \mathrm{a}$ & $71.71 \pm 2.11 \mathrm{a}$ & $73.07 \pm 1.37 \mathrm{a}$ & $72.05 \pm 2.58 \mathrm{a}$ & $72.88 \pm 1.28 \mathrm{a}$ \\
\hline MA60 & $72.66 \pm 1.15 \mathrm{a}$ & $71.34 \pm 2.34 \mathrm{ab}$ & $72.07 \pm 2.26 \mathrm{a}$ & $71.68 \pm 1.65 \mathrm{ab}$ & $71.16 \pm 1.58 \mathrm{a}$ & $71.97 \pm 1.71 \mathrm{abc}$ \\
\hline \multirow[t]{2}{*}{ MA75 } & $71.39 \pm 1.02 \mathrm{a}$ & $71.09 \pm 1.54 \mathrm{ab}$ & $71.62 \pm 2.42 \mathrm{a}$ & $70.64 \pm 1.34 \mathrm{bc}$ & $72.00 \pm 1.89 \mathrm{a}$ & $72.53 \pm 1.56 \mathrm{ab}$ \\
\hline & \multicolumn{6}{|l|}{ Ratio (SSC/TA) } \\
\hline \multirow{2}{*}{$\begin{array}{l}\text { After } \\
\text { harvest }\end{array}$} & & $+4 \mathrm{~d}$ ripening & & $+4 \mathrm{~d}$ ripening & & $+4 \mathrm{~d}$ ripening \\
\hline & $38.19 \pm 2.80 \mathrm{ab}$ & $46.65 \pm 2.36 \mathrm{a}$ & $38.19 \pm 2.80 \mathrm{ab}$ & $46.65 \pm 2.36 \mathrm{ab}$ & $38.19 \pm 2.80 \mathrm{ab}$ & $46.65 \pm 2.36 \mathrm{a}$ \\
\hline \multicolumn{2}{|c|}{ Treatments After $14 \mathrm{~d}$ CS } & $+4 \mathrm{~d}$ ripening & After $21 \mathrm{~d}$ CS & $+4 \mathrm{~d}$ ripening & After $28 \mathrm{~d}$ CS & $+4 \mathrm{~d}$ ripening \\
\hline Control & $42.69 \pm 3.57 \mathrm{a}$ & $48.34 \pm 3.17 \mathrm{a}$ & $44.26 \pm 3.78 \mathrm{a}$ & $54.92 \pm 3.13 \mathrm{a}$ & $44.47 \pm 3.10 \mathrm{a}$ & $51.03 \pm 2.11 \mathrm{a}$ \\
\hline MA30 & $40.10 \pm 2.71 \mathrm{ab}$ & $47.70 \pm 2.65 \mathrm{a}$ & $36.79 \pm 3.60 \mathrm{ab}$ & $48.29 \pm 3.72 b$ & $38.39 \pm 2.59 \mathrm{ab}$ & $50.75 \pm 2.36 \mathrm{a}$ \\
\hline MA50 & $36.12 \pm 3.62 \mathrm{ab}$ & $44.31 \pm 2.84 \mathrm{ab}$ & $35.12 \pm 2.97 \mathrm{ab}$ & $44.51 \pm 2.68 \mathrm{bc}$ & $38.41 \pm 3.91 \mathrm{ab}$ & $55.53 \pm 2.78 \mathrm{a}$ \\
\hline MA60 & $31.91 \pm 2.34 \mathrm{bc}$ & $50.01 \pm 3.01 \mathrm{a}$ & $33.20 \pm 3.66 \mathrm{~b}$ & $44.82 \pm 3.68 \mathrm{bc}$ & $38.13 \pm 3.85 \mathrm{ab}$ & $54.27 \pm 2.46 \mathrm{a}$ \\
\hline MA75 & $29.32 \pm 2.88 \mathrm{c}$ & $35.84 \pm 2.65 \mathrm{~b}$ & $28.98 \pm 2.85 \mathrm{~b}$ & $35.59 \pm 2.26 \mathrm{c}$ & $31.16 \pm 2.82 b$ & $36.18 \pm 2.10 \mathrm{~b}$ \\
\hline
\end{tabular}

${ }^{\mathrm{x}}$ Average $(\mathrm{n}=10)$ and ${ }^{\mathrm{y}}$ Standard deviation.

Control $=$ nonwrapped; MA30 $=$ PEBD30 $\mu \mathrm{m} ;$ MA50 = PEBD50 $\mu \mathrm{m} ;$ MA60 = PEBD60 $\mu \mathrm{m} ;$ MA75 = PEBD75 $\mu \mathrm{m}$.

For each parameter, in the column, same letters no differ significantly between each other, according to Tukey test ( $\mathrm{p} \leq 0.05)$. 


\section{CONCLUSIONS}

1-There is significant difference among the treatments according to Quantitative Descritive Analysis and Principal Component Analysis.

2-The ripe fruits from MA50 and MA60 treatments are characterized by the fresh appearance, fresh peach flavour, juiciness and flesh firmness. These treatments were effective for keeping good quality of 'Douradão' peaches during 28 days of cold storage.

3-The ripe fruits from Control and MA30 treatments are characterized by the mealiness, and those from MA75 treatment showed lower intensity for the attributes evaluated.

4-Higher correlation coefficients (positive) are found between fresh appearance and flesh firmness (0.95), fresh appearance and juiciness (0.97), ratio and intensity of fresh peach smell (0.81), as well as higher correlation coefficients (negative) between Hue angle and intensity of yellow colour $(-0.91)$, fresh appearance and mealiness $(-0.92)$, juiciness and mealiness $(-0.95)$, firmness and mealiness (-0.94).

\section{REFERENCES}

AKBUDAK, B.; ERIS, A. Physical and chemical changes in peaches and nectarines during the modified atmosphere storage. Food Control, Oxford, v.15, n.1, p. 307-313, 2004.

AOAC - Association of Official Analytical Chemists. Official methods of chemists analysis. $17^{\text {th }}$ ed. Arlington, 1995. $1141 \mathrm{p}$.

CHITARRA, M.I.F.; CHITARRA, A.B. Pós-colheita de frutos e hortaliças: fisiologia e manuseio. Lavras: UFLA/FAEPE, 2005. 785 p.

DEILY, K.R.; RIZVI, S.S.H. Optimisation of parameters for packaging of fresh peaches in polymeric films. Horticultural Abstract, Wageningen, v. 53, n. 6, p. 4886-4887, 1983.

DAMASIO, M.H.; COSTELL, E. Análisis sensorial descriptivo: generación de descriptores y seleción de catadores. Revista Agroquímica de Technología de Alimentos, San Jose, v. 31, n. 2, p. 165-178, 1991.
FEIPPE, M.A.; VILLAS BOAS, E.V.B. Estudio de la actividad enzimática post-cosecha de polifenoloxidasa y peroxidasa en durazno. Revista Iberoamericana de Technología Postcosecha, Mexico, v. 3, n. 2, p. 179-184, 2001.

GIRARDI, C.L.; PARUSSOLO, A.; DANIELI, R.; CORRENT, A.R.; ROMBALDI, C.V. Armazenamento de pêssegos (Prunus persica $\mathrm{L}$ Batsch) cv. Chiripá em atmosfera modificada. Revista Iberoamericana de Technología Postcosecha, Mexico, v. 4, n. 2, p. 128-133, 2002.

KADER, A.A. A summary of CA requirements and recommendations for fruit other than pome fruit. In: INTERNATIONAL CONTROLLED ATMOSPHERE RESEARCH CONFERENCE, 7. 1997, Davis. Proceedings...

KADER, A.A.; ZAGORY, D.; KERBEL, E.E.L. Modified atmosphere packaging of fruits and vegetables. Critical Reviews in Food Science and Nutrition, Maryland, v. 28, n.1, p. 1-30, 1989.

MCGUIRRE, R.C. Reporting of objective color measurements. HortScience, Alexandria, v. 27, n.12, p. 1254-1255, 1992.

MOSKOWITZ, H.R. Product testing and sensory evaluation of foods: marketing and $R \& D$ approaches. Westport: Food and Nutrition Press, 1983. 605 p.

SANTOS, C.A.A. Uso de quitosana e embalagem plástica associado à refrigeração na conservação da qualidade de pêssegos 'Douradão' e 'Aurora-1' 2007. 52 f. Dissertation (Agronomy Master) Agronomy Institute of Campinas, Campinas, 2007.

SAS - Statistical Analysis System. User's procedures guide. Version 6. Cary, 2003. 2v

STONE, H.; SIDEL, J.L. Descriptive analysis. In: STONE, H., SIDEL, J.L. Sensory evaluation practices. London: Academic Press, 1985. 311 p.

ZOFFOLI, J.P.; ALDUNCE, J.R.P.; CRISOSTO, C.H. Modified atmosphere in fruits of elegant lady and ohenry peaches. Postharvest News and Information, Amsterdam, v.9, n.3, p.1000-1005, 1998. 